\title{
A Focus on the Play of Elements of Caste in Cyrus Mistry's Chronicle of a Corpse Bearer
}

\section{S. Rema Devi}

\begin{abstract}
Every individual is born with equal rights. No individual is superior to the other. Curtailing freedom of people owes to factors like religion, caste, colour, gender, language etc. Every human being should live with full freedom. However, since time dating back to the ancient days, man has followed the system of caste. Caste determined the status and well-being of a man. The division of castes depended on many external factors like the colour of the skin, the occupation of people, the religious policies, the political backgrounds, the evolutionary factors etc. The occupational theory throws light that there were people who were branded outcastes or untouchables, owing to the jobs they did. On account of the mean jobs done by some people, they were branded untouchables or outcastes. The present paper focuses on the plight of such a group of people, namely the Parsi corpse bearers. The paper is an attempt to trace the elements of social stigmata and sufferings of theses corpse bearers and their plight, struggling to have their rights as normal human beings, in Cyrus Mistry's Chronicle of a Corpse Bearer.
\end{abstract}

Keywords: Elements of caste, Cyrus Mistry, Chronicle of a Corpse Bearer

\section{INTRODUCTION}

$\mathrm{E}_{\mathrm{very}}$ individual is born with equal rights. No individual is superior to the other. Curtailing freedom of people owing to factors like religion, caste, colour, gender, language etc. is highly offensive. Every human being should live with full freedom. However, since time dating back to the ancient days, man has followed the system of caste. Caste determined the status and well-being of a man. The origin of caste system in India dates long back to the invasion of the Aryans. Sources tell that the castes were divided based on many external factors like the traditional beliefs in the Varna system, the religious principles, the occupations of the people, the political factors, the evolutionary backgrounds, etc. Sources state that the castes, in India, developed as per the occupation of the people. Concept of superior and inferior caste also came with this as some persons were doing superior jobs and some were into lower kinds of jobs. All those people who were doing the task of purohits were superior and they were the ones who used to do specialization. Superior caste with time grouped into Brahmins. Similarly, other groups were also formed leading to different castes in India. [1]

The Parsi community in India was, once, considered a minority group. This set of people belongs to the Zoroastrian community. Being immigrants of the earlier centuries, these refugees were considered in minority and were forced to do menial jobs. Web sources observe, "Thousands of migrants instead become victims of labour exploitation, a new form of slavery that occurs on a massive scale. Due to growing inequalities in destination countries, this exploitation is increasingly seen as 'normal'. [2]

\section{SEGREGATION}

The present paper focuses on the play of the elements of caste in Cyrus Mistry's Chronicle of a Corpse Bearer. Many articles have been published focusing the segregation of people on the basis of caste. The present paper focuses both on the elements of caste and the elements of slavery, owing to the status of the untouchables.

\section{CHRONICLE OF A CORPSE BEARER}

The novel is the story of a Parsi corpse bearer, Phiroze Elchidana. He is the son of the priest of the fire temple, Soonamai Ichchaporia Agiari. He falls in love with a forest-nymph like girl Sepideh, the daughter of a Khandhia or a corpse bearer. When Phiroze tells his wish to marry her, her father places a condition that the former should become a corpse bearer and spend his rest of the life in the Tower of Silence. Phiroze too agrees and leaves his family.

Phiroze marries Sepideh and becomes a corpse bearer. He regrets not a moment for having taken this decision. He is of a priestly origin. Nevertheless, he accepts himself to be called a pariah. In spite of being a Nussesalar, who "shields the community from all that evil and putrefaction by absorbing it into his own being" [3], he turns out to be a Khandhia or a corpse bearer. This decision matters a lot because the Parsi corpse bearers were treated as untouchables in the pre-independent years. Phiroze is disowned by his family and he becomes an outcaste, who if enters the house of his parents, would pollute the entire place. He says, "You could say, though, that as a nussesalar, I am a glorified untouchable." [3] He knows that he has lost all privilege and recalls that, "Everything I had once held dear was lost, and forever, I had become a pariah. .." [3]

In the Parsi tradition, a belief prevails that a corpse bearer is "Avestan" or "the Lord of the Unclean" [3]. 
They believe that carrying corpses and performing the putrefaction of the corpses by ritually cleaning them and anointing the corpse with the bull's urine and carrying them to the top of the hill to be fed upon by the vultures is a noble service. They are also certain of the fact that they would be freed from the cycle of rebirth, on account of this noble service. However, these nussesalars are considered "untouchable to the core". [3] Sources state that "The Dalits who handled meat and waste were considered the untouchables and formed the lowest caste." [4]

Phiroze spends the rest of the life, carrying corpses. His happiness does not last long because his wife dies at a very young age, when their daughter Farida is three, bitten by a venomous snake. The novel brings to the forefront the plight of the corpse bearers and their struggle to break the social stigmata.

\section{THE RIGHTS OF THE CORPSE BEARERS}

The present paper focuses on the rights the corpse bearers have been denied, as normal human beings. All human beings should be given equal respect and regard, in spite of the diversities. This aspect is advocated by Julie Stone Peters, when she says, "The rights of man were humane principles, entailing not just claims but obligations, and these not only toward the ordinary run of humanity but toward slaves, the poor, the young, primitives, eventually criminals, and various and sundry other downtrodden persons." [3] The narrator of the novel describes the incidents of humiliation, those set on fire the urge to fight for their basic rights as human beings. The corpse bearers are not considered even as human beings. The narrator says, "A Parsi funeral must be concluded before sunset. In Parsi-populated areas there was certainly no call for vocal histrionics. The sight of four burly men in white muslins, shouldering a corpse on a bier and walking as fast as they could was self- explanatory: the public knew where we were headed, and why in such a hurry.

People made way for us long before we approached. [3]

The corpse bearers are not given any time to relax or have their food. The earlier days of labour did not have time constraints to the workers and they had to work day and night. However, the nineteenth century labour movements are notable for their campaign for an eighthour work per day. The extra work they do would be paid as overtime. As sources aver, the labour movements realized that it is time to "to recall certain fundamental truths and underline the values that are at stake." [3] The protagonist explains the plight of the corpse bearers working for long hours in conditions which they never like and which even the near and the dear ones of the defunct does not do. He writes, "It's a job that takes courage and strength, believe you me - rubbing the dead man's forehead, his chest, palms and the soles of his feet with strong smelling bull's urine, anointing every orifice of the body with it before dressing him up again in fresh muslins and knotting the sacred thread around his waist. All the while making sure the pile of faggots on the censer breathes easy and the oil lamp stays alive through the night; all this, before we retire ourselves well past midnight." [3]
The narrator is nearly exhausted with the continuous work of carrying corpses on to hills in heavy iron biers. Another factor which drains off the energy from these corpse bearers is the smell that emanates from the dead bodies. The narrator writes, "Those damn biers we lug around-solid iron-each weighs nearly eighty pounds! And all corpses aren't emaciated by death, let me tell you. Some positively swell, growing more flaccid by the minute. Besides, how else, I ask you this, how else are the best of us to keep up this carrion work, this constant consanguinity with corpses, without taking a drop or two? The smell of sickness and pus endures; the reek of extinction never leaves the nostril. [3]

The people depend on the corpse bearers to remove the deceased and do not touch them, however close they are related to the dead. Once, Kobaad, a companion of Phiroze asks, "I'd like to see how many of the trustees can cope with even just the sight of an accident victim, or a burns victim-let alone clean and swaddle them for the banquet of the birds." " [3] When Phiroze accidentally bumps into a man who had come for a funeral, the latter gives him a cold look so as to tell him that he has touched an untouchable. The narrator moves away with a smile thinking that one day when the man dies, it would be him who would do his last rites. The narrator says, "Then, ask yourself, will your near and dear ones wash and clothe you for the final goodbye? No, sweet man, you'll have to depend on one of us. And then, we'll have to rub you all over ..." [3]

The living conditions of the corpse bearers, too, are very poor and are unhealthy. The narrator describes his quarters telling, "No, in those early days, our living quarters were not electrified-no electric lights, no fans, no radios. We lived by candlelight and, if we ran out of those, or oil for the lamps, or kerosene, as was so often the case, natural light alone defined the shape of our waking hours." [3]

The worst part of their labour is that the corpse bearers are not given time to relax or eat. They keep on moving to collect corpses to the funeral cottage, wash them clean, anoint them with bull's urine and carry them to the hill tops, to feed the blood thirsty birds. Phiroze is tired both physically and mentally when he thinks of his plight in reporting immediately to another funeral the same day. He reacts to his supervisor Buchia, who tells, "Next funeral has to start at four. If you wait for lunch you'll never make it back before sunset. It'll take you two hours just to reach Colaba." [3] Phiroze pleads to him asking time at least to lunch. He says, "This is too much, saheb. . .even we need to eat some time. And rest. It's heavy work. What's happened to the hearse?"' [3] The Human Rights Act states that under Section 374, "Whoever unlawfully compels any person to labour against the will of that person, shall be punishable with imprisonment of either description for a term which may extend to one year, or with fine, or with both." [3] However, the corpse bearers are treated in a dehumanized way and are denied their basic rights.

On one such occasion, Phiroze collapses along with the corpse. He is hunger stricken and tired due to the lack of food and rest. The corpse falls upside down from the bier, which creates a 
social issue. The corpse bearers are suspended for a week. They are called for an inquiry. Phiroze has to give a proper answer for having caused the "disgraceful incident" [3] of allowing a corpse to topple off the bier, "causing a public outcry" [3] and "shaming the Zoroastrian community." [3] The disciplinary measure of suspending the corpse bearers creates a fear in them because the remaining labourers in the Punchayet would be forced to work double, in the absence of the suspended labourers. This condition resembles slavery, in which the human beings are not provided with a normal work atmosphere and are forced to work double, without duly paid, proper food and rest.

The inquiry is held in the board room of the Punchayet office. People working in the office have an averted look at the suspended corpse bearers, for the reason of being untouchables and for having brought shame to the Zoroastrian community by throwing a corpse on the road. When they are there for the inquiry, which is scheduled at ten in the morning, they hurry without their breakfast. They are kept waiting even after quarter to eleven. Rustom, a companion of Phiroze, feels hungry and expresses his anger to which Fali, another corpse bearer warns him

that he should not feel hungry. He says, "Forget it, Rustom,' ribbed Fali. 'You have no rights, certainly no right to feel hungry. You're suspended, remember?" [3] Another act of dehumanization is sensed when these people are called inside the board room for the inquiry. Phiroze is called in alone, only after warning the other corpse bearers. When he is in, he is not given a seat to sit. He says, "Despite all the empty chairs around the table, of course, I remained standing, and no one asked me to sit." [3] The paradox lies in the fact that the officers tell him that they badly want to dismiss him from his job, but only suspend him, which Phiroze understands is a pretext to impregnate a fear in him. He says, "Staring wordlessly at my self-important interlocutors seated pompous and contented in their polished, cushioned chairs - all three screwing up their faces to appear oh-so terribly concerned for me, while at the same time slightly discomfited by the whiff of some unpleasant odour I had brought in - in one corner of my head, I could sense a reckless wave of giggles building up." [3]

However, the officers, being prejudiced that Phiroze was fully drunk on the day of social shame, succeed in giving him a punishment of probation, in spite of his eight years of service in Doongerwadi. He pleads to them telling, “... madam, but I wasn't drunk. The sun was too hot-it was sunstroke. On top of that I hadn't eaten anything all day.", [3] His plea falls on deaf ears. Phiroze recalls the incident in which his wife Sepideh asks him to protest for rights. He recalls her words saying, "If you guys are so important to the Zarthostis, why don't they provide you better working conditions? It's sheer hypocrisy to say you guys'll have your reward in the next lifetime; yet treat you like offal in this one. . . Why don't you guys get together, do something about it? Protest. . ." [3] This idea brings in him a thought to protest for the basic rights of labourers. The updated news of the movements of freedom struggle and the inbuilt pressure of work drives Phiroze to the state of protest, along with his suspended companions. He says, “... there was a moment of intense, soul-searching silence: for someone posed the question: what're we going to do about this state of affairs? I confess I was the one who first mooted the possibility of protest. A phrase we had all heard on Temoo's radio in the context of Gandhiji's exertions for home rule had been running in my head. And so it was that the idea of some sort of 'peaceful non-cooperation' took root among the corpse bearers, though none of us had any clue what form it should take." [3]

Owing to the seed of protest that he has planted in every corpse bearer, Phiroze and Rustom plan a charter of demands that assure basic human rights and consideration to the labourers. He says, " .... charter of demands; very modest and reasonable ones. Not for better wages, but simply an eight-hour working day, overtime compensation and a fixed entitlement of ten days' casual leave in a year." [3] Having recognized these to be the basic rights of labour, they give their petition enlisting their grievances. However, they are again summoned to meet Coyaji, their superior who condemns them for having behaved like ordinary factory workers. He also tries to entice the labourers saying that the work they did is tremendously religious. He adds that their work has social significance. Phiroze recalls Coyaji's observations saying, "That such demands as we had presented had been made for the first time in the entire history of the community itself showed they were uncalled for! And that he, personally, was very hurt that we should have felt the need to spell out our demands in a formal petition, as though we were members of a trade union.

Instead, if we had only come to him, in the same spirit as a child approaches its father for extra pocket money, he wouldn't have felt such a sense of betrayal. "[3]

However, there is an element of surprise awaiting the petitioners. Coyaji arranges for tea and sandwiches, with which Phiroze and his companions are wonderstruck. They have a doubt if the cups from which they drink would be smashed to pieces for having touched the lips of the untouchable. Warning them saying that in the past one hundred and fifty years, no individual has raised such demands in the Punchayet, Coyaji dismisses them with a fruitless attempt. The narrator says, "Not a single concession was granted to us, even just to mollify or appease- except to proclaim that our grievances would definitely be looked into in greater detail." [3]

On account of this disappointment, Phiroze and his companions plan a three-day strike. Never in history, has one come to know of a strike by the corpse bearers. Though the people of the Punchayet and the superiors are taken aback, they expect that as time moves on the corpse bearers would drop down the strike and normal conditions would prevail. However, it slowly dawns on them that the corpse bearers are really serious when no corpse is removed for the next three days. Social changes take place. The price of ice goes high for the purpose of preserving the dead bodies. Letters flow in to the editors of various newspapers, some ridiculing the corpse bearers and some the society for the inhumane treatment of the corpse bearers. Phiroze writes, "Many of them condemned the Parsi Punchayet for being 'a bunch of lazy and corrupt self-seekers', 'puffed up on privilege', for allowing the situation to get so out of

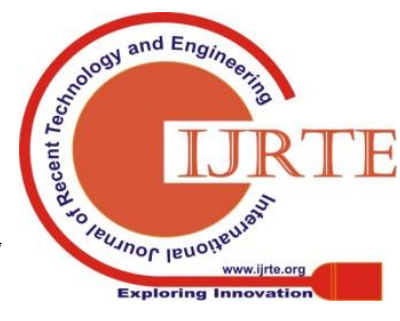


hand, for treating the corpse bearing caste with so much contumely and contempt that they had no option but to fight for their rights by refusing to work." [3]

\section{CONCLUSION}

Controversies brew between the reformist minds of the society and the orthodoxy group. People who value orthodoxy and religious beliefs, state that, “... khandhias had actually dared to 'hold the community to ransom', that we should be 'summarily sacked' and punished 'in the harshest possible way'." [5] However, the orthodoxy protests become feeble attempts. The superiors yield to the demands of the corpse bearers. Phiroze writes, "The strike lasted only three-and-a- half days before the trustees climbed down and granted all our demands, including the provisions for overtime, casual leave and my unconditional reinstatement." [6]

Article 4 of Human Rights tells that, "No one shall be required to perform forced or compulsory labour. For the purpose of this Article the term 'forced or compulsory labour' [7] shall not include any work required to be done in the ordinary course of detention imposed according to the provisions of Article 5 of this Convention or during conditional release from such detention." [8] The select novel portrays how the corpse bearers fight for their rights as labourers and above all, as normal human beings. As Kukathas advocates, "Equality before the law is one of the basic principles of liberalism." [9] As the law states all should be treated equally before the law, without any discrimination on any grounds.

\section{REFERENCES}

1. https://www. mapsofindia.com/my-india /india/castesystem-in-india-and-its-changing-scenario

2. (http://www.unodc.org/unodc/en/frontpage/2011/June/protect-human-righ ts-and-workers-rights-to-end-labour-exploitation.html

3. Mistry, Cyrus. Chronicles of a Corpse Bearer. New Delhi: Aleph Book Company, 2012. Books for Bookies. Web. 22 Feb. 2016. https://booksforbookies.blogspot.com

4. https://www.mapsofindia.com/history/ http://www.lawtutor.in/indian-constitution-for-dummies-equality-be y-be

6. ore-law-and-equal-protection-of-laws/

7. http://www.yourarticlelibrary.com/sociology/essay-on-varna-system-in-in dia-1513-words/4006

8. Peters, Julie Stone, “"Literature”, the Rights of Man and narratives of Atrocity". Theoretical Perspectives on Human Rights and Literature. (2012) 19-40

9. https://www.equalityhumanrights.com/en/human-rights-act/article-4-freed om- slavery-and-forced-labour

10. International Labour Review. Vol. 1/ 137 (1998) No:2 p: 127-33

\section{AUTHOR'S PROFILE}

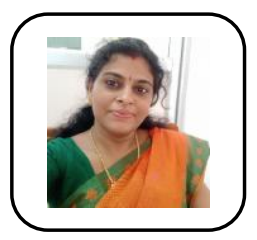

Dr S. Rema Devi is an academician. She has completed her post graduation and doctorate in English literature from the Manonmaniam Sundaranar University in Tamil Nadu, India. She has authored two books, published thirteen papers in various journals and five papers in conference proceedings. She is in the editorial panel of three peer-reviewed journals. She has around fifteen years of experience in the field of teaching English language and literature. She is a member of the Lavender Literary Club. She has received various awards. She, at present, heads the Department of English at Kalasalingam Academy of Research and Education, Krishnankoil, Virudhunagar District, Tamil Nadu, India. 